\title{
Does Green Economy Video Really Work? The Effectiveness of Using Video Content Marketing in Forming MSMEs Perception and Behavior to Implement Green Economy
}

\author{
Rizka Zulfikar *) \\ Prihatini Ade Mayvita**)
}

\begin{abstract}
This study aims to assess the effectiveness of the use of video content marketing in performing SMEs perceptions and behavior in implementing the concept of a green economy. The expected results of this research will make the using of video marketing content can be used as a material consideration for use in socialization and guidance to SMEs about the concept of green economy. This study was conducted in South Kalimantan province with the population, and the sample was SMEs in South Kalimantan province as much as 164 respondents. Researcher use purposive sampling as research method with one group pretest-posttest as research design. The data was collected using interviews and questionnaires. Data analysis technique are descriptive statistics, and Wilcoxon Sign Rank Test. This study found that there is an average difference of perception and behavior of respondents about green economy before and after treatment with the video content marketing.
\end{abstract}

Keywords: Perception; Behavior; Green Economy; MSME; Video Content Marketing

\section{INTRODUCTION}

\subsection{Research Background}

Green economy or environmentally friendly is a business activity that always strives to minimize damage to the environment, such as pollution through the waste produced, and the disruption of the balance of ecosystems and the environment of the communities around the business area. The existence of environmentally friendly businesses is expected to increase the security and sustainability of the ecosystem balance in the future (Bank Indonesia, 2012).

MSMEs (Micro Small and Medium Enterprises) are one of the economic actors who have such a large role in the national economy. When UMKM actors are irresponsible and do not know the concept of green economy, the waste produced can disrupt the environment (Zulfikar \& Mayvita, 2018). This is very unfortunate that understanding the green economy concept is still very far from their daily business activities. Their orientation is only on how the business continues to run and profit can be maximized. There are various challenges related to the adoption of concepts and understanding of a green economy; one of the challenges comes from MSME owners regarding their understanding and willingness to implement this concept. Creativity and innovation are needed to enable better information transfer process that can lead to positive perceptions and behavior for MSMEs to implement green economy.

The Bank Indonesia report (2015) states that most MSMEs that currently exist still do not make the environmentally friendly as things that need special attention. This is caused by several factors such as (a) lack of knowledge of environmental sustainability, (b) weak management aspects, (c) technical aspects that do not support, and (d) the unavailability of financing sources to create an environmentally friendly business. Therefore, the phasing of the environmentally friendly criteria implementation by MSME conditions is needed. For that reason, the implementation of 
socialization and education is very necessary to raise consumer awareness to utilize environmentally friendly products.

While the reason why SMEs have not implemented a green economy in their businesses is because of the lack of knowledge of concepts and benefits and the high application costs that have caused the green economy not to be carried out by them, likewise, the lack of support from the government and related agencies has led to the green economy concept not being implemented by SMEs (Noviardy \& Mellita, 2014). To increase the level of knowledge and awareness, MSMEs must be supported to obtain information and technology that can help them in implementing green economy.

The process of transferring information on the green economy concept can employ video content marketing media which is currently widely used in marketing activities to increase sales and shape consumer image. This media contains elements of education, information, and entertainment so that it can provide added value and is often used as a learning tool to improve audience understanding (Short, 2017). Media Video content marketing will provide positive implications for audience attitudes both from aspects of cognition, affection, and also behavioral (Silaen, 2015; Alksne, 2016; Hidayati, 2017). The educational and information elements in the content are received and well perceived by the audience. Various elements of education, information, entertainment, and absorbed beliefs stimulate the attitude of the audience to be more interested in the content (Silaen, 2015; Hong \& Yang, 2018). Delivering information with attractive visual designs will be able to cause audience attention so that it will form a distinct image of a concept that can be an opportunity for the use of video content marketing in the process of transferring information on the green economy concept to MSMEs.

This research is then conducted to analyze the effectiveness of the use of video content marketing media as an alternative medium for information transfer to facilitate MSMEs in their understanding of the green economy concept which is then expected to form better perceptions and behaviors to implement green economy. It is expected that the results of this study can later be considered as an increase in the effectiveness of the dissemination of the green economy concept.

\subsection{Research Problem}

a) Are there differences in perceptions and behavior of MSMEs before and after watching video content of green marketing?

\subsection{Research Purpose}

The purpose of this study is to obtain empirical evidence about the effectiveness of using video content marketing in shaping perceptions and behavior of MSMEs to implement green economy and the role of the treatment in the form of video content marketing in influencing MSMEs' perceptions and behavior.

\section{THEORETICAL FRAMEWORK AND HYPOTHESES DEVELOPMENT}

\subsection{Green Economy}

MSMEs are not ready to conduct environmentally friendly business activities with constraints like lack of knowledge and awareness of environmentally friendly, limited technical capabilities, limited aspects of capital and weak aspects of management (Bank Indonesia, 2012). The main disadvantage of MSMEs is the limited access to capital, technology, and knowledge (Kruja, 2013). Government support in the provision of technology and information is very influential in encouraging MSMEs to implement the green economy concept (Sriyono, 2014) and the implementation of green economy must be implemented as soon as possible because it has a major 
influence on the environment and humanity (Fauzia, 2016). To increase knowledge and awareness of environmentally friendly, the technology transfer process is a fast way for SMEs to be able to implement environmentally friendly technologies. MSMEs must be supported to obtain information and technology that can help them in implementing green economy.

\subsection{Video Content Marketing}

One technological process that can be used to improve understanding is to use video content marketing media, because video content marketing has a positive influence for audience attitudes in the aspects of cognition, affection, and also behavior (Silaen, 2015). The educational and information elements in the content are accepted and well perceived by the audience. Various elements of education, information, entertainment, and absorbed beliefs stimulate the audience to be more interested in the content (Silaen, 2015). Video media dominates the entry channel of information through the eyes and ears and can improve human memory that comes from what is seen and heard. Messages delivered through video media can also affect emotions and can achieve targeted results faster than other media (Dwyer, 2011). Video-based learning media that is oriented in problem-solving will have a positive influence on learning activities (Agustina, 2012) and the use of interactive video media provides more effective results than other learning media because it increases interest and arouses the audience's appeal to the material (Izzudin, Masugino, \& Suharmanto, 2013). Video content marketing media is a medium that can attract the attention of audiences because it provides the content the audience needs, it does not present the information about the product too much because audience involvement is the key to successful content marketing (Diamond, 2015). The ultimate goal of a video content marketing is to evoke a response from the expected audience, which are the emergence of knowledge of content (cognitive), the emergence feelings towards objects from the content (affection) and the emergence of behavior (behavioral) (Mandloys Digital Marketing, 2013).

\subsection{The Effectiveness of Digital Media in Forming Perception and Behavior}

Some researchers state that the use of digital media tends to be more effective than other media to improve understanding and change audience perceptions, attitudes and behavior (Olofintoye \& Akanle, 2011; Candarli \& Yuksel, 2012; Suduc, Bîzoi, Gorghiu, \& Gorghiu, 2012; Bal-Gezegin, 2014; Petan, Petan, \& Vasiu, 2014; Stanczyk, de Vries, Candel, Muris, \& Bolman, 2015). As stated by Kay (2012) which states that there are significant changes in perceptions and behavior of respondents to continue to preserve the environment after getting digital media treatment such as video podcasts. So it can be said that digital media has a positive influence on the formation of audience perceptions and behavior.

Video media is able to capture $94 \%$ of the entrance channels of messages or information into the human's mind through the eyes and ears and is able to make people, in general, remember 50\% of what they see and hear from program shows. Also, messages delivered through video media can invoke strong emotions and achieve fast results than other media (Dwyer, 2011; Alksne, 2016; Wang \& Antonenko, 2017). Video-based learning media that are problem-solving oriented have a positive influence on learning activities (Agustina, 2012; Hund \& Getrich, 2015; Laaser \& Toloza, 2017; Hong \& Yang, 2018) and the use of interactive video media provides more effective results than other learning media because it increases interest and arouses the audience's appeal to the material (Izzudin, Masugino, \& Suharmanto, 2013; Hund \& Getrich, 2015; Costley \& Lange, 2017; Tackett, Slinn, Marshall, Gaglani, Waldman, \& Desai, 2018).

The hypotheses in this study was formed on the basis of the research results by Olofintoye \& Akanle, 2011; Kay, 2012; Candarli \& Yuksel, 2012; Suduc, Bîzoi, Gorghiu, \& Gorghiu, 2012; Bal- 
Gezegin, 2014; Petan, Petan, \& Vasiu, 2014; Stanczyk, de Vries, Candel, Muris, \& Bolman, 2015, who found that the use of digital media can provide a change in audience perceptions and behavior and can be seen from the difference in audience perceptions and behavior before and after being treated with video content marketing. Based on this, the hypotheses that will be used in this study are as follows:

$\mathrm{H}_{1}$ : There are differences in the average perception of MSMEs in implementing green economy before and after being treated with video content marketing

$\mathrm{H}_{2}$ : There are differences in the average behavior of MSMEs in implementing green economy before and after being treated with video content marketing

\section{RESEARCH METHOD}

\subsection{Research Design}

The study is Pre Experimental research that uses video media as a treatment for transferring information on the green economy concept in socialization activities. The design of this study is based on "One group pretest-posttest design." In this design, before the sample is given the treatment, the initial questionnaire is given first to determine the knowledge, understanding, perception, and behavior of the samples, and the final questionnaire aims to determine knowledge, perception, and behavior of the sample after receiving treatment. This study uses data analysis techniques in the form of (1) Quantitative descriptive analysis, (2) Test the validity and reliability of the instrument and (3) Wilcoxon Sign Rank Test.

\subsection{Population and Sample}

The population and sample in this study are MSMEs in the province of South Kalimantan, and the sampling technique using the Slovin formula as follows:

$$
\mathrm{n}=\frac{\mathrm{N} \cdot \mathrm{Z}^{2} 1-\propto / 2 \cdot \mathrm{p} \cdot(1-\mathrm{p})}{(N-1) d^{2}+\mathrm{Z}^{2} 1-\propto / 2 \cdot \mathrm{p} \cdot(1-\mathrm{p})}
$$

In which :

$\mathrm{n}=$ Minimum number of samples

$\mathrm{Z}=$ Normal Distribution Standard Value (table Z) with $\alpha=0.05$

$\mathrm{p}=$ The proportion of samples in the population

$\mathrm{d}=$ Error rate allowed (Absolute Error)

$\mathrm{N}=$ Population

Based on data obtained from the Department of Cooperatives and SMEs in South Kalimantan province, that until 2017 the number of MSMEs throughout the province of South Kalimantan was 375,000 MSMEs, with a population proportion of $=20 \%$ and an absolute level of error of $5 \%$, the minimum sample used in this study is:

$$
\mathrm{n}=\frac{375.000 \times(1,96)^{2} \times 0.10 \times 0.90}{(374.999) \times(0.05)^{2}+(1,96)^{2} \times 010 \times 0.90}=138 \text { sample }
$$

This study used 164 MSMEs as the respondents to fulfill the minimum number of sample required. The sampling method was done by purposive-sampling technique, and the data was then edited using Microsoft Excel. The material of video content marketing contains elements in the form of education (black economy and its impact on the environment, green economy concept and sustainable development), information (government policy and incentives for environmentally 
friendly MSMEs, as well as entertainment (Story board animation along with dubbing sound that explains the video flow). The technique of making video content marketing was using the Sparkol Video Subscribe Whiteboard Animation Version 2.3.0

\subsection{Research Framework}

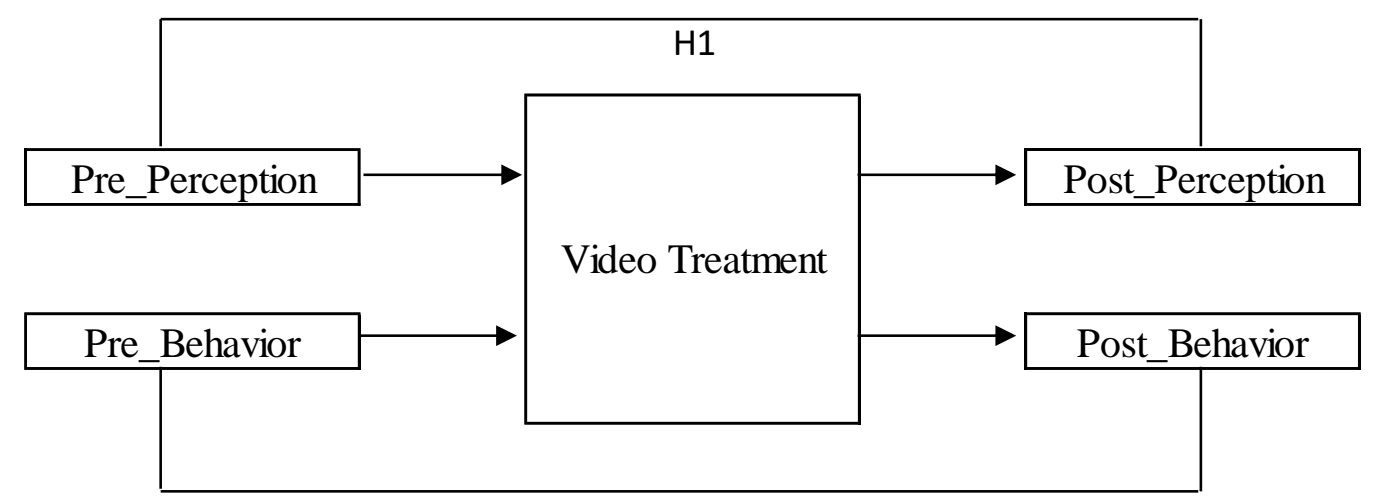

$\mathrm{H} 2$

Picture 1 Research Framework

Where,

Treatment

$=$ The use of video content marketing as a medium for transferring information about the green economy to respondents.

Pre_perception $\quad=$ Respondents' perceptions before getting treatment using video content marketing.

Pre_behavior = Respondent's behavior before getting treatment using video content marketing

Post_perception $\quad=$ Respondents' perception after getting treatment using content marketing video.

Post_behavior = Respondent's behavior after getting treatment using video content marketing.

\section{RESEARCH RESULT AND ANALYSIS}

\subsection{Descriptive Analysis}

Table 1 shows the characteristics of respondents' knowledge level about the green economy:

Table 1 Respondents Knowledge Level About Green Economy

\begin{tabular}{|c|l|c|c|c|}
\hline No & \multicolumn{1}{|c|}{ Knowledge } & High & Moderate & Low \\
\hline 1 & The concept of green economy & $9.8 \%$ & $79.9 \%$ & $10.4 \%$ \\
\hline 2 & The concept of sustainable development & $4.9 \%$ & $80.5 \%$ & $14.6 \%$ \\
\hline 3 & Application of a green economy & $10.4 \%$ & $79.9 \%$ & $9.8 \%$ \\
\hline
\end{tabular}

Source: Primary Data Processed, 2018

Descriptive analysis of the respondents' perceptions and behavioral variables (pre-test) was carried out based on the level of perceptions and behavior of respondents before being treated. Determination of trend categories from each variable is based on the category according to Hadi (2002) and is described in three groups of categories: high, moderate, and low. The categorization 
is based on respondents' assessment (X) compared to the mean (M) and standard deviation (SD) of these variables with the following conditions:

a) high $=\mathrm{X} \geq \mathrm{M}+\mathrm{SD}$

b) moderate $=\mathrm{M}-\mathrm{SD}>\mathrm{X} \geq \mathrm{M}+\mathrm{S}$

c) low $=\mathrm{M}-\mathrm{S}>\mathrm{X}$

Where,

$\mathrm{X}=$ Respondents' assessment of indicators observed

$\mathrm{M}=$ Mean value of overall respondents' rating

$\mathrm{SD}=$ The overall standard deviation of respondents' ratings

Based on the results of the pre-test before being given treatment, the level of perception and behavior of respondents categorized in the following table:

Table 2 Respondents Perception of Green Economy (Pre-Test)

\begin{tabular}{|c|l|c|c|c|}
\hline No & \multicolumn{1}{|c|}{ Perception } & High & Moderate & Low \\
\hline 1 & The cost of implementing green economy (Perc_1) & $12.7 \%$ & $83.9 \%$ & $3.4 \%$ \\
\hline 2 & Use of technology (Perc_2) & $19.2 \%$ & $76.0 \%$ & $4.8 \%$ \\
\hline 3 & Benefits for business (Perc_3) & $24.1 \%$ & $72.3 \%$ & $3.6 \%$ \\
\hline 4 & Ease of application (Perc_4) & $18.7 \%$ & $76.1 \%$ & $5.2 \%$ \\
\hline 5 & Government support (Perc_5) & $16.3 \%$ & $79.6 \%$ & $4.1 \%$ \\
\hline
\end{tabular}

Source: Primary Data Processed, 2018

Table 3 Respondents Behavior in Implementing the Green Economy (Pre-Test)

\begin{tabular}{|c|l|c|c|c|}
\hline No & \multicolumn{1}{|c|}{ Behavior } & High & Moderate & Low \\
\hline 1 & A desire to apply (Bhv_1) & $22.1 \%$ & $71.0 \%$ & $6.9 \%$ \\
\hline 2 & A desire to find information (Bhv_2) & $26.0 \%$ & $64.6 \%$ & $9.4 \%$ \\
\hline 3 & A desire to encourage others (Bhv_3) & $24.2 \%$ & $66.0 \%$ & $9.9 \%$ \\
\hline 4 & Desire inform (Bhv_4) & $15.6 \%$ & $76.3 \%$ & $8.1 \%$ \\
\hline 5 & $\begin{array}{l}\text { A desire to make a business that is environmentally friendly } \\
\text { (Bhv_5) }\end{array}$ & $32.5 \%$ & $57.8 \%$ & $9.6 \%$ \\
\hline
\end{tabular}

Source: Primary Data Processed, 2018

Based on the results in table 3, it is seen that MSMEs in the province of South Kalimantan already had a good level of knowledge, perception, and behavior about the green economy concept, in which the results of categorization of the assessment are mostly in the moderate category.

Based on the results of the post-test after being given treatment, the level of perception and behavior of respondents is categorized in the following table:

Table 4 Level of Respondent's Perception of Green Economy (Post-Test)

\begin{tabular}{|c|l|c|c|c|}
\hline No & \multicolumn{1}{|c|}{ Perception } & High & Moderate & Low \\
\hline 1 & The cost of implementing green economy (Perc_1) & $56.4 \%$ & $43.3 \%$ & $0.3 \%$ \\
\hline 2 & Use of technology (Perc_2) & $65.1 \%$ & $33.6 \%$ & $1.3 \%$ \\
\hline 3 & Benefits for business (Perc_3) & $66.3 \%$ & $33.0 \%$ & $0.7 \%$ \\
\hline 4 & Ease of application (Perc_4) & $58.2 \%$ & $40.6 \%$ & $1.2 \%$ \\
\hline 5 & Government support (Perc_5) & $56.5 \%$ & $41.7 \%$ & $1.8 \%$ \\
\hline
\end{tabular}

Source: Primary Data Processed, 2018 
Table 5 Respondents' behavior in implementing the Green Economy (Post-Test)

\begin{tabular}{|c|l|c|c|c|}
\hline No & \multicolumn{1}{|c|}{ Behavior } & High & Moderate & Low \\
\hline 1 & A desire to apply (Bhv_1) & $63.2 \%$ & $35.6 \%$ & $1.3 \%$ \\
\hline 2 & A desire to find information (Bhv_2) & $68.4 \%$ & $29.4 \%$ & $2.2 \%$ \\
\hline 3 & A desire to encourage others (Bhv_3) & $67.1 \%$ & $31.8 \%$ & $1.1 \%$ \\
\hline 4 & Desire inform (Bhv_4) & $66.3 \%$ & $31.5 \%$ & $2.1 \%$ \\
\hline 5 & $\begin{array}{l}\text { A desire to make a business that is environmentally friendly } \\
\text { (Bhv_5) }\end{array}$ & $72.3 \%$ & $25.4 \%$ & $2.3 \%$ \\
\hline
\end{tabular}

Source: Primary Data Processed, 2018

Based on the results in table 5, it can be seen that the knowledge, perceptions, and behavior of MSMEs in South Kalimantan province have increased due to the treatment in the form of video content marketing, where the results of the assessment of the respondents after being treated were mostly in the high category. The effectiveness of green economy campaign videos in providing an understanding of the green economy concepts have been categorized in the following table:

Table 6 Effectiveness of Videos on Green Economy Campaigns

\begin{tabular}{|c|l|c|c|c|}
\hline No & \multicolumn{1}{|c|}{ Description } & High & Moderate & Low \\
\hline 1 & Helps to understand the concept of a green economy & $54.3 \%$ & $42.7 \%$ & $3.0 \%$ \\
\hline 2 & Helps to understand the application of a green economy & $56.1 \%$ & $39.6 \%$ & $4.3 \%$ \\
\hline 3 & Helps to explain government policies & $64.0 \%$ & $29.3 \%$ & $6.7 \%$ \\
\hline 4 & $\begin{array}{l}\text { Motivates the application of green economy in the business } \\
\text { environment }\end{array}$ & $68.3 \%$ & $26.8 \%$ & $4.9 \%$ \\
\hline 5 & Motivates to invite others to implement a green economy & $51.8 \%$ & $40.2 \%$ & $7.9 \%$ \\
\hline
\end{tabular}

Source: Primary Data Processed, 2018

Based on the table above, it can be seen that MSMEs in the province of South Kalimantan have assumed that the green economy campaign video is quite effective in providing information and understanding of the green economy, while the dominant level of assessment is in the high category.

\subsection{Validity and Reliability}

Table 7 Validity Test

\begin{tabular}{|c|c|c|c|c|}
\hline No & Item & Pearson Correlation & Sig. (1-Tailed) & Decision \\
\hline 1 & Perc_1 & 0.812 & 0.000 & Valid \\
\hline 2 & Perc_2 & 0.885 & 0.000 & Valid \\
\hline 3 & Perc_3 & 0.580 & 0.000 & Valid \\
\hline 4 & Perc_4 & 0.825 & 0.000 & Valid \\
\hline 5 & Perc_5 & 0.883 & 0.000 & Valid \\
\hline 6 & Bhv_1 & 0.993 & 0.000 & Valid \\
\hline 7 & Bhv_2 & 0.940 & 0.000 & Valid \\
\hline 8 & Bhv_3 & 0.794 & 0.000 & Valid \\
\hline 9 & Bhv_4 & 0.850 & 0.000 & Valid \\
\hline 10 & Bhv_5 & 0.930 & 0.000 & Valid \\
\hline
\end{tabular}

Source: Primary Data Processed, 2018 
The results of the validity of statement items can be seen in table 7 . The reliability was tested using the value of Cronbach's alpha that if the test results were above 0.60 , then it can be concluded that all items are reliable.

Table 8 Reliability Test

\begin{tabular}{|c|c|}
\hline Cronbach's Alpha & N of Items \\
\hline 0.960 & 10 \\
\hline
\end{tabular}

Source: Primary Data Processed, 2018

Based on this result, it can be said that the questionnaire used in this study has very high reliability because the value of Cronbach's alpha instrument is 0.960 .

\subsection{Research Analysis}

Hypotheses Testing 1 and 2 were performed to see whether there are differences in respondents' perceptions and behavior towards the video content marketing treatment using the Wilcoxon sign rank test and the test results are presented in the table below:

Table 9 Wilcoxon Sign Rank Test

\begin{tabular}{|l|r|r|}
\hline & Pre_Perception - Post_Perception & Pre_Behavior - Post_Behavior \\
\hline Z & $-12.143^{\mathrm{b}}$ & $-11.266^{\mathrm{c}}$ \\
\hline Asymp. Sig. (2-tailed) & .000 & .000 \\
\hline
\end{tabular}

a. Wilcoxon Signed Ranks Test

b. Based on positive ranks.

c. Based on negative ranks.

Based on the table above, the results of the analysis can be conveyed as follows:

- It can be seen that the significance value of pre-post perception is $<0.05$, which means that there are significant differences in the perceptions and behavior of respondents before and after being treated with content marketing videos, so $\mathrm{H}_{1}$ is accepted.

- It can be seen that the significance value of pre-post behavior is $<0.05$, which means that there are significant differences in the behavior of respondents before and after being treated with content marketing videos, so $\mathrm{H}_{2}$ is accepted.

\subsection{Research Discussion}

From the results of the research hypotheses test, it is found that there are differences in the mean of perception and behavior before and after given treatment with video content marketing. This is in line with the findings of Dwyer (2011), Agustina (2012), Izzudin, Masugino, \& Suharmanto (2013, Silaen (2015), which states that video media can influence the emotions of a strong audience, it can also achieve faster results than any other media and can provide positive implications for audience attitudes both from aspects of cognition, affection, and behavioral. This is also supported by the opinions of Olofintoye \& Akanle (2011); Kay (2012); Candarli \& Yuksel (2012); Suduc, Bîzoi, Gorghiu, \& Gorghiu (2012); Izzudin, Masugino, \& Suharmanto (2013), BalGezegin, (2014); Petan, Petan, \& Vasiu (2014); Stanzyk et al (2015) and Diamond (2015). The use of video is able to provide changes in the mean of perception and behavior of MSMEs in implementing the green economy concept because the video media can capture $94 \%$ of the entry channel of information through the eyes and ears and can improve human memory that comes from what is seen and heard. Messages delivered through video media can also affect emotions and can achieve targeted results faster than other media (Dwyer, 2011; Alksne, 2016; Wang \& Antonenko, 
2017). Video-based learning media that is oriented in problem-solving will have a positive influence on learning activities (Agustina, 2012; Hund \& Getrich, 2015; Laaser \& Toloza, 2017; Hong \& Yang, 2018) and the use of interactive video media provides more effective results than other learning media because it increases interest and arouses the audience's appeal to the material (Izzudin, Masugino, \& Suharmanto, 2013; Hund \& Getrich, 2015; Costley \& Lange, 2017; Tackett, Slinn, Marshall, Gaglani, Waldman, \& Desai, 2018). So that the use of video content marketing can be considered as a medium for transferring information about the green economy.

\section{RESEARCH CONCLUSION AND LIMITATION}

\subsection{Conclusion}

Based on the results of data analysis and the findings of research facts, then some conclusions that can be taken are as follows:

a) There are differences in the mean between the pre and post perception of respondents after being given the treatment of video content marketing.

b) There are differences in the mean between the pre and post behavior of respondents after being given the treatment of video content marketing.

c) MSMEs in the province of South Kalimantan have assumed that the green economy campaign video is quite effective in providing information and understanding of the green economy

\subsection{Limitation}

Based on the identification of problems, this study only examines the effectiveness of using video content marketing to invoke the perceptions and behavior of MSMEs. This study does not examine the influence of the elements in video content marketing such as education, information, and entertainment elements. By knowing the effectiveness of the use of video content marketing in green economy socialization, it can be a consideration for relevant parties to arrange further socialization strategies.

\section{REFERENCES}
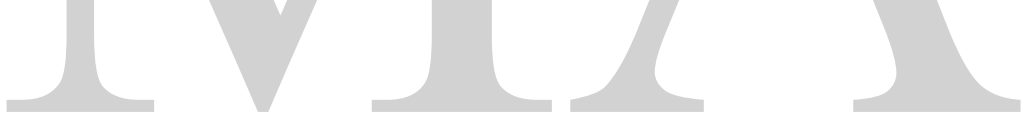

Agustina, A. (2012). Pengembangan Media Pembelajaran Video Untuk Melatih Kemampuan Memecahkan Masalah Pada Materi Larutan Asam Basa. Journal of Chemical Education, 1(1), 10-16.

Alksne, L. (2016). How to produce video lectures to engage students and deliver the maximum amount of information. Proceedings of the International Scientific Conference, 503(2), 516.

Bal-Gezegin, B. (2014). An investigation of using video vs. audio for teaching vocabulary. Procedia-Social and Behavioral Sciences, 143, 450-457.

Bank Indonesia. (2012). Kajian Kesiapan UMKM Ramah Lingkungan Dalam Mendapatkan Akses Pembiayaan. Laporan Akhir. Jakarta.

Bank Indonesia. (2015). Profil Bisnis Usaha Mikro Kecil Menengah (UMKM). Laporan Akhir. Jakarta.

Candarli, D., \& Yuksel, H. G. (2012). Students' perceptions of video-conferencing in the classrooms in higher education. Procedia-Social and Behavioral Sciences, 47, 357-361.

Costley, J., \& Lange, C. H. (2017). Video lectures in e-learning: effects of viewership and media diversity on learning, satisfaction, engagement, interest, and future behavioral 
intention. Interactive Technology and Smart Education, 14(1), 14-30. https://doi.org/10.1108/ITSE-08-2016-0025.

Diamond, S. (2015). The Visual Marketing Revolution. Edisi 1. Jakarta: Serambi Ilmu Semesta

Dwyer, J. (2011). The Bussines Communication Handbook. Ninth Edition. Melbourne Victoria: Pearson Education

Fauzia, I. Y. (2016). Urgensi Implementasi Green Economy Perspektif Pendekatan Dharuriyah Dalam Maqashid Al-Shariah. Jurnal Ekonomi dan Bisnis Islam, 2(1), 87-104. http://dx.doi.org/10.20473/jebis.V212016.\%25p.

Hadi, S. (2002). Metode Teknik Penelitian Kualitatif dan Kuantitatif. Surakarta: Universitas Negeri Surakarta.

Hund, L., \& Getrich, C. (2015). A pilot study of short computing video tutorials in a graduate public health biostatistics course. Journal of Statistics Education, 23(2). https://doi.org/10.1080/10691898.2015.11889736.

Hidayati, R. (2017). Video Production Process As A Learning Tool To Increase Training Participants'learning Motivation In Achieving Learning Goal A Case Study Of Diklatprajabatan (Prajabatan Training) Golongan III Year 2015 At Pusdiklatperdagangan. Cendekia Niaga, 1(1), 104-113.

Hong, J., Pi, Z., \& Yang, J. (2018). Learning declarative and procedural knowledge via video lectures: cognitive load and learning effectiveness. Innovations in Education and Teaching International, 55(1), 74-81. https://doi.org/10.1080/14703297.2016.1237371.

Izzudin, A. M., Masugino, \& Suharmanto, A. (2013). Efektivitas Penggunaan Media Pembelajaran Video Interaktif Untuk Meningkatkan Hasil Belajar Praktik Service Engine Dan KomponenKomponennya. Automotive Science and Education Journal, 2(2), 18-26.

Kay, R. H. (2012). Exploring the Use of Video Podcast in Education: A Comprehensive Review of The Literature. Computers in Human Behavior, 28(3), 820-831. https://doi.org/10.1016/j.chb.2012.01.011.

Kruja, A. (2013). The Contribution of SMEs to the Economic Growth (Case of Albania). Journal BRAND (Broad Research in Accounting, Negotiation, and Distribution), 4(1), 31-42.

Laaser, W., \& Toloza, E. A. (2017). The changing role of the educational video in higher distance education. The International Review of Research in Open and Distributed Learning, 18(2). https://doi.org/10.19173/irrodl.v18i2.3067.

Mandloys, D. M. (2013). Content Marketing Essentials 2013. Retrieved from http://www.mandloys.com/contentmarketing/.

Noviardy, A, \& Mellita, D. (2014). Implementasi Green Marketing Pada Usaha Kecil Menengah di Kota Palembang. Seminar Nasional and Call For Paper Economic Globalization: Trend \& Risk for Developing Country.

Olofintoye, T. T., \& Akanle, F. F. (2011). The effects of e-mail, video and lecturing methods on sexual risk reduction among adolescents: Counselling for Hiv/Aids prevention. Procedia Computer Science, 3, 47-51. https://doi.org/10.1016/j.procs.2010.12.009. 
Petan, A. S., Petan, L., \& Vasiu, R. (2014). Interactive video in knowledge management: Implications for organizational leadership. Procedia-Social and Behavioral Sciences, 124, 478-485. https://doi.org/10.1016/j.sbspro.2014.02.510.

Short, R. (2017). Video Content Marketing : Measuring Success. Retrieved from http://frozenfire.com/what-is-video-content-marketing/.

Silaen, P.I. (2015). Promosi Pariwisata Melalui Content Marketing. Electronic Thesis and Disertation Gadjah Mada University. Universitas Gadjah Mada. Yogyakarta.

Sriyono. (2014). Implementation of Green Economy on The Development of SMEs in Sidoarjo District. The third International Conference On Entrepreneurship and Business Management (ICEBM) Penang.

Stanczyk, N. E., de Vries, H., Candel, M. J. J. M., Muris, J. W. M., \& Bolman, C. A. W. (2016). Effectiveness of Video-Versus Text-Based Computer-Tailored Smoking Cessation Interventions Among Smokers After One Year. Preventive Medicine, 82, 42-50. https://doi.org/10.1016/j.ypmed.2015.11.002.

Suduc, A. M., Bîzoi, M., Gorghiu, G., \& Gorghiu, L. M. (2012). Digital images, video and web conferences in education: a case study. Procedia-Social and Behavioral Sciences, 46, 41024106.

Tackett, S., Slinn, K., Marshall, T., Gaglani, S., Waldman, V., \& Desai, R. (2018). Medical education videos for the world: an analysis of viewing patterns for a YouTube channel. Academic Medicine, 93(8),

$1150-1156$. https://doi.org/10.1097/ACM.0000000000002118.

Van der Meij, H., \& van der Meij, J. (2016). The effects of reviews in video tutorials. Journal of computer assisted learning, 32(4), 332-344. https://doi.org/10.1111/jcal.12136.

Wang, J., \& Antonenko, P. D. (2017). Instructor presence in instructional video: Effects on visual attention, recall, and perceived learning. Computers in Human Behavior, 71, 79-89. https://doi.org/10.1016/j.chb.2017.01.049.

Zulfikar, R., \& Mayvita, P. A. (2018). The Relationship of Perceived Value, Perceived Risk, and Level of Trust Towards Green Products of Fast Moving Consumer Goods Purchase Intention. JEMA: Jurnal Ilmiah Bidang Akuntansi dan Manajemen, 15(2), 1-14. http://dx.doi.org/10.31106/jema.v15i2.838.

\section{ACKNOWLEDGEMENT}

This study was conducted under the cooperation between the Islamic University of Kalimantan in the supervision of Community Service and Research Bureau (LPPM-UNISKA) and Directorate of Research and Community Service (DRPM-DIKTI) financing years of 2018. The research team was conveying great gratitude to the Director General of Higher Education (DIRJEN-DIKTI), who was supporting this research in their program in 2018. 
*) Rizka Zulfikar, Department of Management, Islamic University of Kalimantan Muhammad Arsyad Al Banjari Banjarmasin, Banjarmasin, Indonesia (Email : rizkazulfikar@gmail.com)

**) Prihatini Ade Mayvita, Department of Management, Islamic University of Kalimantan Muhammad Arsyad Al Banjari Banjarmasin, Banjarmasin, Indonesia (Email : ademayvita@gmail.com)

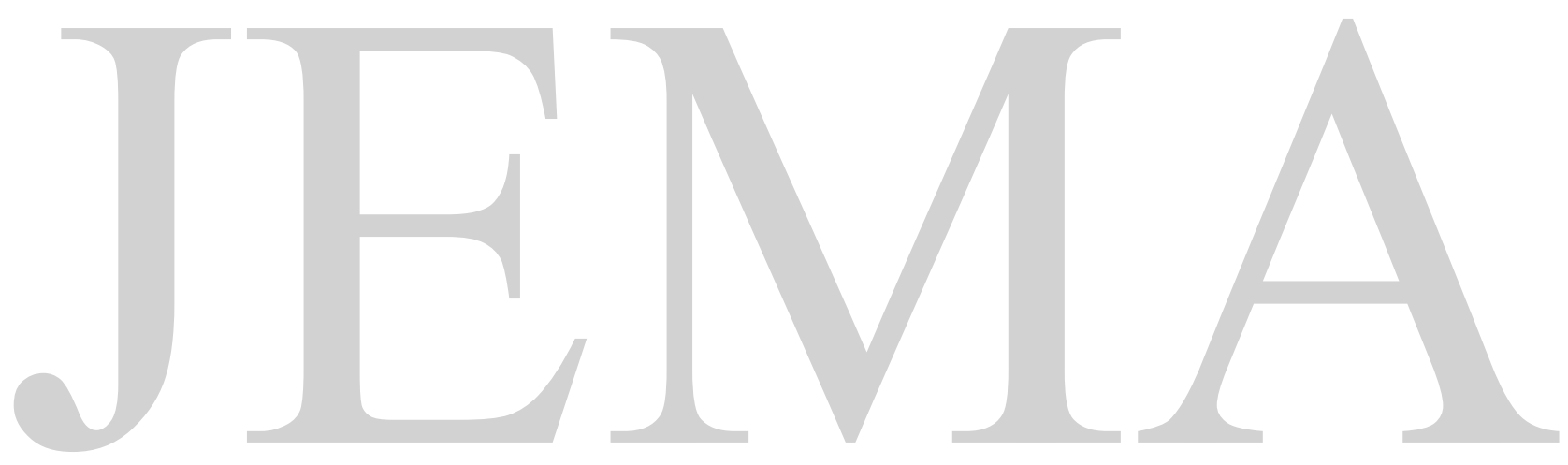

